\author{
산란계의 육성기 제한급여가 체성장 특성 및 내분비 변화에 \\ 미치는 영향 \\ 강환구* · 조재훈** · 김지혁* - 강근호* · 유동조* - 나재천* · 김동욱* . 이상진* · 김인식*** · 김상호* \\ 농촌진흥청 축산과학원 가금과*, 부천축협**, 전북대학교 수의학과***
}

\title{
Effects of Restricted Feeding during Growing Period on Growth and Endocrine Profile in Layers
}

Hwan Ku Kang*, Jae Hoon Cho**, Ji Hyuk Kim*, Geun Ho Kang*, Dong Jo Yu*, Jae Cheon ${ }^{*}$, Dong Wook Kim*, Sang Jin Lee*, In Shik Kim*** and Sang Ho Kim*

Poultry Science Division, Livestock Resource Development, National Institute of Animal Science, RDA* Buchon National Livestock Cooperatives Federation**,

Department of Veterinary Anatomy, Chonbuk National University***

\begin{abstract}
The objective of this study was to investigate the effect of restricted feeding to pullet on growth and endocrine profile in layers (Isa brown).

One thousand eighty brown-layer chicks were divided into three treatments; conventional feeding (ad libitum) and two restricted feedings ( $80 \%$ of conventional diet) for 70 weeks. One of restricted feeding started from seven to seventeen weeks of age, and the other started from twelve to seventeen weeks of age. Diets were formulated by NRC (1994) recommendation. Body weight and feed intake were measured every two weeks, and body composition and organ weight analyzed every week in rearing period and every eight weeks in laying period. Blood was collected at weighing body weight and was analyzed for the concentration of insulin-like growth factor- I and estradiol. Body weight and feed intake decreased as restriction of feeding begins comparing to ad libitum group $(\mathrm{P}<0.05)$, but reached to similar body weight and feed intake at $20 \mathrm{wk}$ of age regardless of restriction. There were no significant differences in development of digestive tract and attached organs among the treatment groups. During rearing period, however, they were slightly higher in restricted group which was low in body weight. In terms of body composition, fat contents of restricted group were significantly lower $(\mathrm{P}<0.05)$ than that of ad libitum group around 1,000 grams of body weight. High concentration of IGF- I was observed.
\end{abstract}

(Key words : Layers, Restricted feeding, IGF- I , ad libitum)

\section{I. 서 론}

오늘날의 산란계는 유전, 육종 및 사양기술 의 향상에 의해 산란능력이 지속적으로 향상되 어지고 있다. 현재 개량된 산란계의 산란시기
는 성성숙 등의 시기가 빨라지면서 약 19 주령 에 산란을 시작하여 몇 주 이내에 최고 산란 시점에 도달하고 있다. 따라서 대부분의 산란 계 농가들은 조기 성성숙을 유도하는 것이 더 욱 경제적 이점을 갖기 때문에 성성숙을 빠르

Corresponding author : S. H. Kim, National Institute of Animal Science, RDA.

Tel : 041-580-6709, Fax : 041-580-6719, E-mail : shkim@rda.go.kr 
게 유도하는 방향의 육성 프로그램을 강조하여 왔다.

산란계 육성 프로그램에 관한 연구는 목표체 중보다는 체성장의 패턴, 생리적 메커니즘 구 명을 위해 실시되고 있지만 다소 미흡한 점들 이 많은 실정이다. 또한 산란계의 경우 육성기 간 동안에 에너지 또는 단백질의 제한, 제한강 도, 제한기간, 제한시기 등의 특정 급여전략으 로 인해 조직과 기관의 성장기간, 영양소 분배 변화, 기별 성장패턴 변화, 발달과정에서 내분 비적 변화 등의 생리적 변화가 일어나고 산란 개시, 산란율, 난질 및 난중 등의 산란능력에 영향을 받는다 (Kwakkel 등, 1993). 국내의 경우 산란기를 대비한 균형있는 체조직 성장과 증체 를 위한 육성기 제한급여 방법 등이 있으나 현 실적으로는 조기산란 유도방법이 일반적이며 이러한 문제점들을 근거로 산란계 육성기 제한 의 급여시기 및 제한강도에 대한 정확한 구명 이 요구되어지고 있다 (김 등, 2003).

국내의 경우 한국표준가축사료급여기준(닭) (1994)에서 육성기를 초생추기(0 6주), 중추기 (6 14주), 대추기(14 18주), 산란예비기(18 20 주)의 네 단계로 구분하여 기별 Step-down 프로 그램이 적용되고 있으며 육성기 사료는 표준체 중 및 증체량을 고려하여 양적제한 급여방법이 주로 사용되어지고 있다.

육성기의 영양상태를 최적화시키기 위해 적 정 목표체중과 생산성 사이의 생리적인 관계, 성장 패턴 및 체조성 변화, 내분비적 변화 및 번식기관 발달 등을 구명하기 위한 다양한 사 양 프로그램을 제시하는 연구들이 진행되어 왔 다. 최소한의 산란 전 체중은 산란개시에 필수 적이지만(Dunnington 등, 1983; Dunnington과 Siegel, 1984), Wells(1980)는 단지 18주령 체중 으로 산란능력을 판단하는 것은 무리가 있기 때문에 18 주령까지 체중의 분리가 고려되어져 야 한다고 하였다.

Wells(1980)는 지방이 과도하게 축적되는 것 을 막기 위해 사료섭취가 과도해지는 육성중기 (7 15주령)에 급여를 제한하는 방법을 제시하 였는데, 이 방법은 산란개시 3주전에 자유채식
으로 보상성장 및 사료 섭취욕을 증가시켜야 한다고 하였다.

Hollands와 Gowe(1961)는 제한급여로 인한 스 트레스가 내분비선을 자극하고 산란을 자극한 다고 하였으며, Frankham과 Doornenbal(1970), Watson(1975)은 성선자극호르몬 생산, 난소와 난관의 민감도 증가는 난관을 크게 하고 난포 성숙을 빠르게 하여 산란자극을 유도한다고 하 였다.

따라서 본 연구는 산란능력에 영향을 미치는 육성기의 적정 급여 방법을 제시하기 위한 목 적으로 육성기 제한시기를 달리하였을 때 나 타나는 기별 체성장 특성, 생리적 변화, 내분 비적 변화를 조사함으로서 조직과 기관발달 및 생리적 상태에 대한 변화를 구명하고자 실 시하였다.

\section{ㅍ. 재료 및 방법}

\section{1. 시험동물 및 시험설계}

본 시험은 1 일령 갈색산란계 Isa-Brown 총 1,080수를 3처리, 6반복으로 반복당 60수씩 공 시하여 농촌진흥청 축산과학원 가금과 시험계 사에서 육성기에 제한 급여를 실시하였다. 육 성기의 시험사료는 3 개로 구분하여 대조구 $(\mathrm{C})$ 는 전기간 자유채식으로 급여하였으며, $\mathrm{T} 1$ 처 리구는 6주령까지는 자유채식 시키고 이후 18 주령까지 대조구 대비 $80 \%$ 로 양적제한급여를 실시하였으며, $\mathrm{T} 2$ 는 12 주령까지 자유채식한 후 18 주령까지 $80 \%$ 로 양적제한급여를 실시하였다.

\section{2. 시험사료 및 사양관리}

시험사료는 Table 1에서 나타낸바와 같이 옥 수수-대두박을 위주의 가루사료 형태로 하여 $\mathrm{NRC}(1994)$ 에 준한 영양소로서 배합하였다. 점 등은 하지까지 자연일조로 하였으며 하지 이후 1 주일에 15 분씩 점증점등하여 17 시간으로 고정 하였는데 최종 점등시간은 04:00부터 21:00까지 17 시간 점등을 실시하였다. 
Table 1. Formular and chemical composition of basal diet

\begin{tabular}{lccccc}
\hline & $\begin{array}{c}\text { Starter } \\
(0-6 w k s)\end{array}$ & $\begin{array}{c}\text { Grower } \\
(7-12 w k s)\end{array}$ & $\begin{array}{c}\text { Developer } \\
(13-18 w k s)\end{array}$ & $\begin{array}{c}\text { Prelayer } \\
(19-20 w k s)\end{array}$ & $\begin{array}{c}\text { Layer } \\
\text { (20wks later) }\end{array}$ \\
\hline \hline Ingredients & & & & & \\
Corn & 65.870 & 57.759 & 58.300 & 63.300 & 67.620 \\
Soybean meal & 30.500 & 16.680 & 13.800 & 12.600 & 16.300 \\
Corn gluten meal & - & - & - & 5.670 & 5.000 \\
Soybean Oil & - & 2.350 & 3.260 & 0.650 & 0.650 \\
Wheat bran & - & 20.000 & 21.500 & 12.000 & - \\
Methionine & - & - & - & - & 0.082 \\
Lysine & - & - & - & - & 0.098 \\
Tricalciumphosphate & 1.150 & 1.249 & 1.000 & 1.330 & 0.950 \\
Limestone & 1.580 & 1.062 & 1.240 & 3.700 & 8.450 \\
Salt & 0.250 & 0.250 & 0.250 & 0.250 & 0.250 \\
Vit-Min. premix* & 0.500 & 0.500 & 0.500 & 0.500 & 0.500 \\
Anticocci & 0.050 & 0.050 & 0.050 & - & - \\
Antibiotics & 0.100 & 0.100 & 0.100 & - & 0.100 \\
Total & 100.00 & 100.00 & 100.00 & 100.00 & 100.00 \\
\hline Chemical composition** & & & & & \\
$\quad$ ME, kcal/kg & 2,923 & 2,800 & 2,852 & 2,855 & 2,904 \\
Crude Protein, \% & 19.02 & 15.00 & 13.99 & 15.98 & 16.04 \\
Lysine, \% & 1.015 & 0.739 & 0.672 & 0.654 & 0.768 \\
Methionine, \% & 0.301 & 0.242 & 0.228 & 0.294 & 0.332 \\
Ca, \% & 0.903 & 0.804 & 0.803 & 1.870 & 3.511 \\
Non Phytate P, \% & 0.396 & 0.350 & 0.300 & 0.352 & 0.276 \\
\hline
\end{tabular}

* Supplied followings per $\mathrm{kg}$ of the premix: vit. A, 1,600,000 IU; vit. $\mathrm{D}_{3}, 300,000 \mathrm{IU}$; vit. E, $800 \mathrm{IU}$; vit. $\mathrm{K}_{3}$, $132 \mathrm{mg}$; vit. $\mathrm{B}_{2}, 1,000 \mathrm{mg}$; Vit. $\mathrm{B}_{12}, 1,200 \mathrm{mg}$; niacin, 2,000 mg; pantothenate calcium, $800 \mathrm{mg}$; folic acid, $60 \mathrm{mg}$; choline chloride, 35,000 mg; dl-methionine, 6,000 mg; iron, 4,000m;; copper, $500 \mathrm{mg}$; manganese, 12,000 mg; zinc, 9,000 mg; cobalt, $100 \mathrm{mg}$; BHT, 6,000 mg; iodine, $250 \mathrm{mg}$.

** Calculated values.

\section{3. 조사항목 및 방법}

(1) 증체량, 사료섭취량, 장기조사 및 체성분 시험개시 후 8주령부터 20주령까지 2주 간격 으로 사료 섭취량를 조사하였으며 각 처리별 6 수씩 임의로 선발하여 체중을 측정하고 방혈을 실시한 후 장기조사를 실시하였다. 각 장기무 게 및 길이 조사를 위해 선위, 근위, 십이지장, 공장, 회장, 맹장, 결-직장, 간 및 비장의 내용 물을 제거하여 무게와 길이를 조사한 후 각 기 관은 깃털과 피부를 제거한 도체와 혼합 - 분쇄 한 후 homogenizer로 균질화하여 수분, 지방, 단백질 및 회분을 AOAC(1995) 방법에 준하여
체성분 분석을 실시하였다.

(2) 혈청 estradiol 농도

혈청 내 estradiol의 농도는 RIA kit (CoatA-Count; DPC, Los Angeles, CA)를 이용하여 측정하였다. 사용한 estradiol의 intra-assay coefficients의 변이는 각각 $8 \%, 10.22 \%$ 였다.

(3) Insulin-like growth factor-1의 방사면역 측정

혈액 내 IGFs (insulin-like growth factor)는 IGFBPs (insulin-like growth factor binding protein) 와 결합된 형태로 존재하므로 IGFBPs로부터 
IGFs를 분리하기 위하여 aced-ethanol extraction (Daughaday, 1978) 방법에 의하여 분리하였다. IGF- I 의 분리는 혈청 $200 \mu$ 에 aced-ethanol(2 M HC1: ethanol = 1:7) $800 \mu$ 를 첨가하여 혼합 한 다음 실온에서 30 분간 원심분리하여 유리형 과 결합형을 분리시켰다. 그 후 $3000 \mathrm{rpm}, 4^{\circ} \mathrm{C}$ 에 서 30 분간 원심분리하여 유리 IGF- I 을 함유하 는 상층액 $500 \mu \ell$ 에 $0.8555 \mathrm{M}$ trizma base를 200 $\mu l$ 넣어 분석에 사용하였으며 IGF-I의 추적자 제조를 제조하고자 Chloramin-T(Lee 등, 1990) 방법을 변형시켜 제조하였다. [ $\left.{ }^{125} \mathrm{I}\right] \mathrm{IGF}-\mathrm{II}$ 추적 자는 sephadex G-50 (Pharmacia LKB, Biotechnology $\mathrm{AB}$, Sweden) column을 통하여 $0.2 \mathrm{M}$ sodium phosphate buffer( $0.2 \%$ BSA 포함)에 용출 시켜 위와 같은 방법으로 분획 수집하여 방사 능을 측정하여 $-70^{\circ} \mathrm{C}$ 에 냉동보관 하였으며 측 정법은 $\left[{ }^{125} \mathrm{I}\right] \mathrm{IGFs}$ 에 polyclonal anti-IGFs를 사용 한 방사면역 측정법 (radioimmunoassay, RIA)을 이용하였다. 이를 요약하면, IGF-1의 측정 RIA 완충액은 $0.5 \% \mathrm{BSA}, 0.12 \mathrm{M} \mathrm{NaCl}, 0.1 \%$ sodium azide를 함유한 $0.04 \mathrm{M}$ sodium phosphate buffer $(\mathrm{pH}$ 7.4)을 사용하였다. IGF-1 표준액과 시료에 1000 배 희석시킨 polyclonal anti-I GF-1 $50 \mathrm{ul}$ 와 12\% polyethylene glycol \#8000 (PEG) $1 \mathrm{ml}$ 를 첨
가하여 $3000 \mathrm{rpm}$ 에서 30 분간 원심분리시켜 결 합형과 비결합형을 분리시켰고 결합형의 방사 능을 gamma counter (Packard, ILL, USA)로 측정 하였다.

\section{4. 통계처리}

본 실험에서 얻어진 자료의 분석은 SAS (SAS Institute, 1996) 프로그램을 이용하여 GLM방식으로 분산분석을 실시하였으며, 처리 별 유의성 분석은 Duncan's new multiple range test를 이용하여 $5 \%$ 수준에서 유의성을 검증하 였다.

\section{III. 결과 및 고찰}

\section{1. 증체량 및 사료 섭취량}

제한시기에 따른 처리별 체중 변화를 조사한 결과는 Table 2에서 나타내었다. 체중은 대조구 에 비하여 $\mathrm{T} 1$ 처리구와 $\mathrm{T} 2$ 처리구에서 각각 사 료 제한급여시점부터 18 주령까지 증체량이 유 의적으로 감소하였으나 $(\mathrm{P}<0.05), 20$ 주령 이후에 는 대조구와 비슷한 양상을 나타내었다.

Table 2. Effect of restricted feeding during growing period on body weight

\begin{tabular}{ccccc}
\hline Week of age & $\mathrm{C}$ & $\mathrm{T} 1$ & $\mathrm{~T} 2$ & SEM \\
\hline \hline & $\ldots \ldots \ldots \ldots \ldots \ldots \ldots \ldots \ldots \ldots \ldots \ldots \ldots \ldots \ldots \ldots \ldots \ldots \ldots \ldots \ldots \ldots \ldots \ldots$ & \\
10 & $643^{\mathrm{a}}$ & $554^{\mathrm{b}}$ & $643^{\mathrm{a}}$ & 10.03 \\
12 & $888^{\mathrm{a}}$ & $775^{\mathrm{b}}$ & $888^{\mathrm{a}}$ & 11.34 \\
14 & $1,126^{\mathrm{a}}$ & $853^{\mathrm{b}}$ & $1,126^{\mathrm{a}}$ & 7.92 \\
16 & $1,269^{\mathrm{a}}$ & $1,074^{\mathrm{c}}$ & $1,163^{\mathrm{b}}$ & 8.31 \\
18 & $1,430^{\mathrm{a}}$ & $1,251^{\mathrm{c}}$ & $1,321^{\mathrm{b}}$ & 13.21 \\
20 & $1,624^{\mathrm{a}}$ & $1,516^{\mathrm{b}}$ & $1,641^{\mathrm{a}}$ & 18.52 \\
24 & 1,671 & 1,670 & 1,706 & 16.02 \\
40 & 1,635 & 1,581 & 1,696 & 19.30 \\
70 & 1,866 & 1,904 & 1,926 & 18.96 \\
\hline $\mathrm{C}$ & 1,926 & 1,935 & 1,939 & 15.34 \\
\hline
\end{tabular}

$\mathrm{C}$; control, T1; restricted feeding started from six to eighteen weeks of age, T2; restricted feeding started from twelve to seventeen weeks of age.

a-c Means within columns with no common superscript differ significantly $(\mathrm{P}<0.05)$ 
Wilson 등 (1983)은 육용종계에서 육성기인 8 24주령에 격일급여법과 단백질 질적 제한급 여법으로 육성된 계군의 체중은 자유급여에 비 하여 감소하였다고 하였으나 Fattori 등 (1993)은 사료 제한 프로그램의 제한강도 증가의 영향은 생리적인 변화 없이 단지 성장만이 지연되는 것이라고 보고하였다. 따라서, 본 결과에서는 제한급여 기간동안 대조구에 비해 체중이 감소 하였으며 제한강도와 제한시기 등은 산란 직전 보상성장을 자극하기 위해 중요하게 여겨지는 데 본 시험의 결과 20 주령 이후에는 대조구와 비교하였을 때 유의차가 나타나지 않으므로 충 분한 보상성장이 이뤄졌다고 사료된다.

제한급여 시기에 따른 처리구별 주간 사료섭 취량의 결과는 Table 3에서 나타내었다. 육성기 동안 사료섭취량은 $\mathrm{T} 1$ 처리구와 $\mathrm{T} 2$ 처리구에 서 대조구에 비해 유의적으로 감소하였으며 $(\mathrm{P}<0.05)$, 시험 전기간에서 제한기간이 길었던 $\mathrm{T} 1$ 처리구에서 $73.16 \mathrm{~g}$ 으로 가장 많이 감소하는 것으로 나타났다 $(\mathrm{P}<0.05)$.

\section{2. 장기 변화}

(1) 소화기관의 상대적 중량 및 길이 변화 처리구별 소화기관의 주령별 무게변화는 Table 4에서 나타내었다. 십이지장, 공장, 회장, 맹장, 결장은 전반적으로 성장초기에는 각 소 화기관의 중량이 체중에 비해 다소 높게 나타 났으나 이후 체중이 증가함에 따라 비율이 점 차 감소되는 추세를 보였으며 산란시기부터는 전 기간동안 일정한 비율로 유지되었다. 처리 구별 소화기관 무게변화에 유의성은 나타나지 않았으나 증체량에서 유의적인 차이를 보였던 사료제한시기에 제한급여 처리구가 대조구에 비하여 비율이 유의적으로 높은 경향을 나타내 었다 $(\mathrm{P}<0.05)$.

선위와 근위의 체중대비 무게변화는 Table 5 에서 나타내었다. 선위와 근위의 무게변화는 각각 12 주령과 20 주령에 $\mathrm{T} 1$ 처리구에서 3.23 , $0.33 \mathrm{~g}$ 으로 유의적인 차이를 나타내었다 $(\mathrm{P}<0.05)$. 십이지장, 공장, 회장, 맹장, 결장의 길이는 부 화 후 성장이 진행되면서 급격히 감소하였는데 성성숙 시점인 12 14주령까지 감소되었다가 그 이후 전 기간동안 일정비율을 유지하였는데 (Table 6) 이는 Katanbaf 등(1988)의 결과와 일 치하였다.

Table 3. Effect of restricted feeding during growing period on feed intake

\begin{tabular}{|c|c|c|c|c|}
\hline Week of age & $\mathrm{C}$ & $\mathrm{T} 1$ & $\mathrm{~T} 2$ & SEM \\
\hline & , n...... & g/bird & ............. & \\
\hline 8 & $57.64^{\mathrm{a}}$ & $50.34^{\mathrm{b}}$ & $57.64^{\mathrm{a}}$ & 0.04 \\
\hline 10 & $73.90^{\mathrm{a}}$ & $57.28^{\mathrm{b}}$ & $73.90^{\mathrm{a}}$ & 0.10 \\
\hline 12 & $87.87^{\mathrm{a}}$ & $55.94^{\mathrm{b}}$ & $87.87^{\mathrm{a}}$ & 0.37 \\
\hline 14 & $94.97^{\mathrm{a}}$ & $65.61^{\mathrm{b}}$ & $63.42^{\mathrm{b}}$ & 0.70 \\
\hline 16 & $80.15^{\mathrm{a}}$ & $68.77^{\mathrm{b}}$ & $67.80^{\mathrm{b}}$ & 0.30 \\
\hline 18 & $80.77^{\mathrm{a}}$ & $72.24^{\mathrm{b}}$ & $71.95^{\mathrm{b}}$ & 0.34 \\
\hline 20 & $76.70^{\mathrm{b}}$ & $91.55^{\mathrm{a}}$ & $86.88^{\mathrm{a}}$ & 1.54 \\
\hline 24 & 95.44 & 99.17 & 95.26 & 1.97 \\
\hline 40 & 124 & 121 & 123 & 1.88 \\
\hline 70 & 110 & 108 & 110 & 1.69 \\
\hline
\end{tabular}

C ; control, T1 ; restricted feeding started from six to eighteen weeks of age, T2 ; restricted feeding started from twelve to seventeen weeks of age.

${ }^{\mathrm{a}-\mathrm{c}}$ Means within columns with no common superscript differ significantly $(\mathrm{P}<0.05)$. 
Table 4. Effect of restricted feeding during growing period on relative intestine weight

\begin{tabular}{|c|c|c|c|c|c|c|c|c|c|c|}
\hline & \multicolumn{10}{|c|}{ Week of age } \\
\hline & 8 & 10 & 12 & 14 & 16 & 18 & 20 & 24 & 40 & 70 \\
\hline Duodenum & \multicolumn{10}{|c|}{ 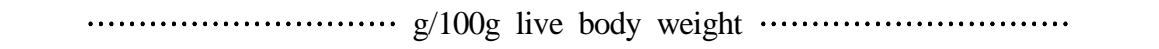 } \\
\hline $\mathrm{C}$ & 0.59 & 0.71 & $0.58^{\mathrm{b}}$ & 0.47 & 0.36 & 0.33 & 0.31 & 0.39 & 0.33 & 0.36 \\
\hline $\mathrm{T} 1$ & 0.73 & 0.70 & $0.71^{\mathrm{a}}$ & 0.54 & 0.32 & 0.30 & 0.28 & 0.33 & 0.33 & 0.32 \\
\hline $\mathrm{T} 2$ & 0.59 & 0.71 & $0.58^{\mathrm{b}}$ & 0.52 & 0.30 & 0.33 & 0.33 & 0.41 & 0.31 & 0.33 \\
\hline SEM & 0.05 & 0.05 & 0.03 & 0.04 & 0.02 & 0.02 & 0.02 & 0.02 & 0.03 & 0.05 \\
\hline Jejunum & \multicolumn{10}{|c|}{ 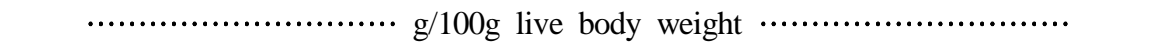 } \\
\hline $\mathrm{C}$ & 0.99 & 1.12 & 0.97 & 0.84 & $0.60^{\mathrm{a}}$ & 0.51 & 0.47 & 0.59 & 0.47 & 0.59 \\
\hline $\mathrm{T} 1$ & 1.05 & 1.22 & 0.94 & 0.89 & $0.57^{\mathrm{a}}$ & 0.50 & 0.44 & 0.50 & 0.52 & 0.56 \\
\hline $\mathrm{T} 2$ & 0.99 & 1.12 & 0.97 & 0.79 & $0.44^{\mathrm{b}}$ & 0.53 & 0.46 & 0.58 & 0.46 & 0.57 \\
\hline SEM & 0.08 & 0.03 & 0.05 & 0.05 & 0.04 & 0.03 & 0.03 & 0.03 & 0.04 & 0.03 \\
\hline Ileum & \multicolumn{10}{|c|}{ 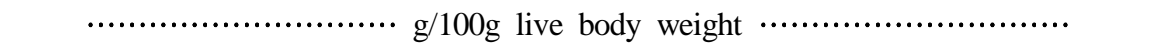 } \\
\hline $\mathrm{C}$ & $0.76^{\mathrm{a}}$ & 0.78 & 0.63 & 0.57 & 0.52 & 0.37 & 0.33 & $0.47^{\mathrm{a}}$ & 0.51 & 0.50 \\
\hline $\mathrm{T} 1$ & $0.63^{\mathrm{b}}$ & 0.82 & 0.58 & 0.60 & 0.43 & 0.41 & 0.34 & $0.34^{\mathrm{b}}$ & 0.48 & 0.49 \\
\hline $\mathrm{T} 2$ & $0.76^{\mathrm{a}}$ & 0.78 & 0.63 & 0.57 & 0.44 & 0.42 & 0.37 & $0.40^{\mathrm{ab}}$ & 0.50 & 0.50 \\
\hline SEM & 0.04 & 0.04 & 0.03 & 0.03 & 0.05 & 0.02 & 0.03 & 0.02 & 0.03 & 0.02 \\
\hline Cecum & \multicolumn{10}{|c|}{ 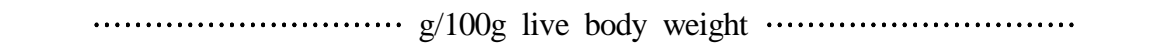 } \\
\hline $\mathrm{C}$ & 0.51 & 0.52 & 0.40 & 0.40 & 0.32 & 0.27 & 0.22 & 0.29 & 0.28 & 0.25 \\
\hline $\mathrm{T} 1$ & 0.52 & 0.50 & 0.39 & 0.42 & 0.30 & 0.31 & 0.26 & 0.25 & 0.26 & 0.26 \\
\hline $\mathrm{T} 2$ & 0.51 & 0.52 & 0.40 & 0.40 & 0.28 & 0.28 & 0.27 & 0.20 & 0.26 & 0.24 \\
\hline SEM & 0.03 & 0.03 & 0.02 & 0.02 & 0.02 & 0.02 & 0.02 & 0.04 & 0.03 & 0.02 \\
\hline Colon & \multicolumn{10}{|c|}{ 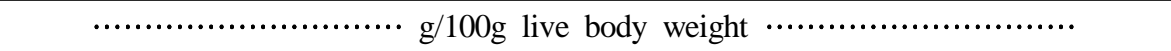 } \\
\hline $\mathrm{C}$ & 0.21 & 0.21 & 0.25 & $0.23^{\mathrm{a}}$ & 0.18 & 0.19 & 0.15 & 0.14 & 0.16 & 0.16 \\
\hline $\mathrm{T} 1$ & 0.25 & 0.26 & 0.25 & $0.19^{\mathrm{b}}$ & 0.19 & 0.16 & 0.18 & 0.16 & 0.19 & 0.15 \\
\hline $\mathrm{T} 2$ & 0.21 & 0.21 & 0.25 & $0.23^{\mathrm{a}}$ & 0.16 & 0.22 & 0.19 & 0.17 & 0.17 & 0.17 \\
\hline SEM & 0.02 & 0.02 & 0.02 & 0.01 & 0.01 & 0.01 & 0.01 & 0.02 & 0.02 & 0.02 \\
\hline
\end{tabular}

$\mathrm{C}$; control, $\mathrm{T} 1$; restricted feeding started from six to eighteen weeks of age, $\mathrm{T} 2$; restricted feeding started from twelve to seventeen weeks of age.

a,b Means within columns with no common superscript differ significantly $(\mathrm{P}<0.05)$.

(2) 간, 비장의 상대적 중량 변화

각 처리에 따른 간과 비장의 체중대비 무게 변화는 Table 7에 나타내었다. 간 중량은 12 주 차에서 $\mathrm{T} 1$ 처리구가 $3.18 \mathrm{~g}$ 으로 다른 처리구와 비교하였을 때 유의적으로 높게 나타났으나 $(\mathrm{P}<0.05), 12$ 주령 이후 다른 처리구와 비교하였 을 때 유의적 차이는 나타나지 않았다. 비장의 중량의 경우도 $\mathrm{T} 1$ 처리구는 제한급여시점 이후 대조구에 비해 유의적으로 감소하였으나 $(\mathrm{P}<0.05)$, 14 주령 이후 기간에서 각 처리구간 유의적 차
이는 나타나지 않았다.

Katanbaf 등(1989)은 산란 육성기 제한급여 방법별 비교 시험에서 처리별 체중대비 간의 중량은 성성숙 개시시점을 제외하고는 일령이 지날수록 감소하였다고 보고하여 본 연구결과 와 일치하였다. 반면 Palo 등(1995)은 육용계 초기 제한급여 처리구의 간의 중량은 대조구에 비하여 높게 나타났다고 하였으며, 자유채식시 점 이후에는 다른 처리구와 동일한 경향을 나 타내었다고 하였다. 
Table 5. Effect of restricted feeding during growing period on relative gizzard and proventriculus weight

\begin{tabular}{|c|c|c|c|c|c|c|c|c|}
\hline & \multicolumn{8}{|c|}{ Week of age } \\
\hline & 12 & 14 & 16 & 18 & 20 & 24 & 40 & 70 \\
\hline Gizzard & \multicolumn{8}{|c|}{ 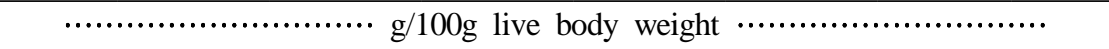 } \\
\hline $\mathrm{C}$ & $3.00^{\mathrm{b}}$ & 3.19 & 2.58 & 2.33 & 1.84 & 1.48 & 1.82 & 1.83 \\
\hline $\mathrm{T} 1$ & $3.23^{\mathrm{a}}$ & 2.78 & 2.59 & 2.65 & 1.96 & 1.60 & 1.78 & 1.80 \\
\hline $\mathrm{T} 2$ & $3.00^{\mathrm{b}}$ & 2.87 & 2.43 & 2.28 & 1.82 & 1.77 & 1.80 & 1.78 \\
\hline SEM & 0.14 & 0.13 & 0.11 & 0.17 & 0.08 & 0.12 & 0.14 & 0.13 \\
\hline Proventriculus & \multicolumn{8}{|c|}{ 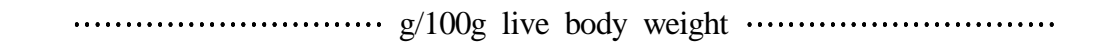 } \\
\hline $\mathrm{C}$ & $0.34^{\mathrm{b}}$ & 0.40 & 0.32 & 0.31 & $0.24^{\mathrm{b}}$ & 0.30 & 0.32 & 0.34 \\
\hline $\mathrm{T} 1$ & $0.43^{\mathrm{a}}$ & 0.38 & 0.37 & 0.34 & $0.33^{\mathrm{a}}$ & 0.29 & 0.33 & 0.33 \\
\hline $\mathrm{T} 2$ & $0.34^{\mathrm{b}}$ & 0.39 & 0.31 & 0.33 & $0.31^{\mathrm{a}}$ & 0.29 & 0.29 & 0.33 \\
\hline SEM & 0.02 & 0.02 & 0.02 & 0.01 & 0.01 & 0.02 & 0.03 & 0.02 \\
\hline
\end{tabular}

$\mathrm{C}$; control, T1 ; restricted feeding started from six to eighteen weeks of age, T2 ; restricted feeding started from twelve to seventeen weeks of age.

a,b Means within columns with no common superscript differ significantly $(\mathrm{P}<0.05)$.

(3) 체조성 변화

처리구별 체조성 결과는 Table 8에 나타내었 다. 수분함량과 회분의 함량은 제한급여 처리 구인 $\mathrm{T} 1$ 처리구와 $\mathrm{T} 2$ 처리구에서 대조구와 비 슷한 수준을 나타내었으나 제한급여 처리시점 에 $\mathrm{T} 1$ 처리구의 수분 함량이 $72.28 \%$ 로 다른 처리구에 비해서 유의적으로 높게 나타났다 $(\mathrm{P}<$ 0.05). 지방 함량은 $\mathrm{T} 1$ 처리구에서 제한시점 이 후 20주령까지 다른 처리구에 비해 유의적으로 낮은 수준으로 유지되었다가 $(\mathrm{P}<0.05)$ 다시 증가 하는 결과를 나타내었다. 단백질 함량은 $\mathrm{T} 1$ 처 리구가 $19.35 \%$ 로 다른 처리구에 비해서 육성기 간동안 유의적으로 높게 나타났으나 $(\mathrm{P}<0.05)$, 18 주령 이후에는 각 처리간 사이에 차이가 나 타나지 않았다.

\section{3. 번식기관 발달 비교}

처리구별 난소와 난관의 전반적 비율은 Fig. 1,2 에서 각각 나타내었다. 난소는 11 주령부터 형태적으로 분열되는 양상을 나타내었으며, 17 주령까지 무게는 차이가 없었으나, 난소의 형 태는 성장이 진행되거나 발달되는 등 분열이 지속적으로 진행되었다. 17주령 이후 난소의 무게는 급격히 증가하였는데, 산란피크기에 최
대의 비율을 나타내었다. 처리구별 체중의 차 가 있었던 육성기 때에는 $\mathrm{T} 1$ 처리구에서 가장 낮은 비율을 보였으나, 산란개시 시점부터는 비슷한 비율을 보였다. 난관의 발달 역시 난소 의 발달과 비슷한 양상을 보였는데 더 급격하 게 발달되는 양상을 보였다. 특히 20주령에 가 장 높은 비율을 보이는 것으로 나타났다.

이와 김(1974)은 육용종계의 제한강도 시험에 서 번식기관의 무게와 난관의 길이에 의해 성 성숙의 정도를 판단하였는데 제한급여는 자유 채식에 비해 번식기관의 무게, 난관의 길이가 유의적으로 낮게 나타났다고 보고하였으며, Melnychuk 등(2004)은 육용종계의 제한급여시 험에서 난소의 상대무게는 자유채식이 제한처 리보다 높게 나타났으나, 난관의 상대무게는 제한급여가 자유채식구 비해 유의적으로 증가 하였다고 보고하였다.

본 연구의 결과에서 난소와 난관발달은 유의 적인 차이를 나타내지 않았는데 이는 상기연구 들에 비하여 제한강도가 낮았기 때문으로 생각 된다. 난소 및 난관의 무게는 Fig. 1에서 나타 낸 바와 같이 20 주령의 경우 $\mathrm{T} 1$ 처리구가 높 게 나타나지 않았는데 이러한 결과는 제한급여 가 번식기관의 발달에 영향을 미치는 것으로 사료된다. 
Table 6. Effect of restricted feeding during growing period on relative intestine length

\begin{tabular}{|c|c|c|c|c|c|c|c|c|c|c|}
\hline & \multicolumn{10}{|c|}{ Week of age } \\
\hline & 8 & 10 & 12 & 14 & 16 & 18 & 20 & 24 & 40 & 70 \\
\hline Duodenum & \multicolumn{10}{|c|}{ 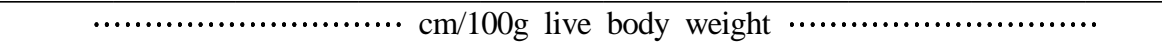 } \\
\hline $\mathrm{C}$ & $2.46^{\mathrm{b}}$ & $2.49^{\mathrm{b}}$ & $2.01^{\mathrm{b}}$ & $1.78^{\mathrm{b}}$ & 1.74 & 1.65 & 1.70 & 1.80 & 1.78 & 1.80 \\
\hline $\mathrm{T} 1$ & $3.28^{\mathrm{a}}$ & $3.04^{\mathrm{a}}$ & $2.64^{\mathrm{a}}$ & $2.19^{\mathrm{a}}$ & 1.98 & 1.89 & 1.72 & 1.74 & 1.77 & 1.81 \\
\hline $\mathrm{T} 2$ & $2.46^{\mathrm{b}}$ & $2.49^{\mathrm{b}}$ & $2.01^{\mathrm{b}}$ & $1.97^{\mathrm{ab}}$ & 1.90 & 1.74 & 1.77 & 1.80 & 1.80 & 1.80 \\
\hline SEM & 0.12 & 0.15 & 0.10 & 0.08 & 0.10 & 0.10 & 0.05 & 0.09 & 0.04 & 0.02 \\
\hline Jejunum & \multicolumn{10}{|c|}{ 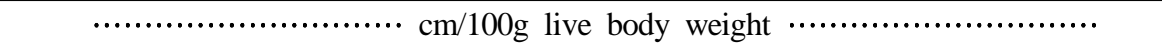 } \\
\hline $\mathrm{C}$ & $6.16^{\mathrm{b}}$ & $5.67^{\mathrm{b}}$ & $4.56^{\mathrm{b}}$ & 4.21 & 3.78 & 3.49 & $3.73^{\mathrm{a}}$ & 3.87 & 3.84 & 3.82 \\
\hline $\mathrm{T} 1$ & $7.99^{\mathrm{a}}$ & $6.84^{\mathrm{a}}$ & $5.73^{\mathrm{a}}$ & 4.62 & 4.09 & 3.92 & $3.08^{\mathrm{b}}$ & 3.69 & 3.76 & 3.80 \\
\hline $\mathrm{T} 2$ & $6.16^{\mathrm{a}}$ & $5.67^{\mathrm{b}}$ & $4.56^{\mathrm{b}}$ & 4.23 & 3.62 & 3.68 & $3.47^{\mathrm{ab}}$ & 4.18 & 3.88 & 3.84 \\
\hline SEM & 0.35 & 0.29 & 0.18 & 0.16 & 0.17 & 0.16 & 0.14 & 0.29 & 0.16 & 0.15 \\
\hline Ileum & \multicolumn{10}{|c|}{ 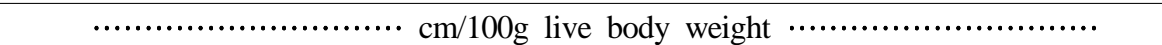 } \\
\hline $\mathrm{C}$ & $5.44^{\mathrm{b}}$ & $5.03^{\mathrm{b}}$ & $4.17^{\mathrm{b}}$ & 3.88 & 3.33 & 3.27 & $3.51^{\mathrm{a}}$ & 3.60 & 3.61 & 3.65 \\
\hline $\mathrm{T} 1$ & $6.85^{\mathrm{a}}$ & $6.37^{\mathrm{a}}$ & $5.22^{\mathrm{a}}$ & 4.02 & 3.54 & 3.48 & $2.99^{\mathrm{b}}$ & 3.55 & 3.58 & 3.70 \\
\hline $\mathrm{T} 2$ & $5.44^{\mathrm{b}}$ & $5.03^{b}$ & $4.17^{\mathrm{b}}$ & 3.83 & 3.37 & 3.57 & $3.29^{\mathrm{ab}}$ & 4.00 & 3.69 & 3.66 \\
\hline SEM & 0.39 & 0.26 & 0.20 & 0.20 & 0.17 & 0.11 & 0.10 & 0.07 & 0.08 & 0.10 \\
\hline Cecum & \multicolumn{10}{|c|}{ 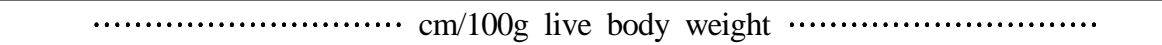 } \\
\hline $\mathrm{C}$ & $1.48^{\mathrm{b}}$ & $1.40^{\mathrm{b}}$ & $1.26^{\mathrm{b}}$ & 1.12 & 1.09 & 1.07 & 1.06 & 1.09 & 1.08 & 1.08 \\
\hline $\mathrm{T} 1$ & $1.91^{\mathrm{a}}$ & $1.67^{\mathrm{a}}$ & $1.62^{\mathrm{a}}$ & 1.25 & 1.22 & 1.13 & 0.95 & 1.05 & 1.06 & 1.07 \\
\hline $\mathrm{T} 2$ & $1.48^{\mathrm{b}}$ & $1.40^{\mathrm{b}}$ & $1.26^{\mathrm{b}}$ & 1.24 & 1.11 & 1.15 & 1.05 & 1.20 & 1.07 & 1.08 \\
\hline SEM & 0.05 & 0.05 & 0.05 & 0.06 & 0.05 & 0.04 & 0.07 & 0.08 & 0.04 & 0.05 \\
\hline Colon & \multicolumn{10}{|c|}{ 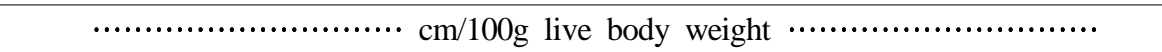 } \\
\hline $\mathrm{C}$ & $0.67^{\mathrm{b}}$ & $0.73^{\mathrm{b}}$ & 0.72 & 0.60 & 0.58 & 0.57 & 0.57 & 0.61 & 0.62 & 0.61 \\
\hline $\mathrm{T} 1$ & $1.10^{\mathrm{a}}$ & $0.93^{\mathrm{a}}$ & 0.85 & 0.59 & 0.61 & 0.55 & 0.53 & 0.58 & 0.59 & 0.60 \\
\hline $\mathrm{T} 2$ & $0.67^{\mathrm{b}}$ & $0.73^{\mathrm{b}}$ & 0.72 & 0.66 & 0.53 & 0.64 & 0.58 & 0.65 & 0.61 & 0.59 \\
\hline SEM & 0.07 & 0.04 & 0.04 & 0.02 & 0.03 & 0.03 & 0.03 & 0.05 & 0.03 & 0.03 \\
\hline
\end{tabular}

$\mathrm{C}$; control, T1 ; restricted feeding started from six to eighteen weeks of age, T2 ; restricted feeding started from twelve to seventeen weeks of age.

a,b Means within columns with no common superscript differ significantly $(\mathrm{P}<0.05)$.

\section{4. 호르몬 변화}

처리구별 IGF- I 의 농도는 Fig. 3에서 나타내 었다. 대조구의 경우 부화 후 급격히 증가하여 16 주령에 $26.73 \mathrm{ng} / \mathrm{ml}$ 로 다른 처리구에 비해 높 게 나타났으나 이후 급격히 감소하였다. $\mathrm{T} 1$ 처 리구에서는 제한급여 개시기인 6주령에 4.04 $\mathrm{ng} / \mathrm{ml}$ 의 처리구간 비교 시 유의적으로 낮아졌 다가 이후 16 주령까지 서서히 증가하였다.

IGF- I 은 단백질 합성을 향상시키고 단백질 의 감소를 지연시키는 것으로 알려져 있으나 (Fryburg, 1994), 단백질의 전반적인 대사작용에
서 그 역할은 아직 명확하게 구명되지 않았다. Darras 등 (1995)은 사료제한이 IGF- I 가 같은 에너지 대사나 성장에 관련된 혈장 호르몬의 수준을 바꾼다고 보고했는데 Gonzales 등 (1998) 은 육용계 수컷을 대상으로 한 제한급여시험에 서 제한급여이전에 IGF-I 의 수준은 처리구별 로 동일한 수준을 유지했지만 제한급여가 시작 된 이후 IGF-I 수준은 제한급여 처리에서 낮아 졌다고 보고하였다. 따라서, 본 연구결과에서도 제한급여 처리시점 이후 IGF- I 은 급격하게 감 소하는 경향을 나타났으나 자유채식시점 이후 에는 대조구 대비 높은 수준으로 지속되었다 
Table 7. Effect of restricted feeding during growing period on relative liver and spleen weight

\begin{tabular}{|c|c|c|c|c|c|c|c|c|c|c|}
\hline & \multicolumn{10}{|c|}{ Week of age } \\
\hline & 8 & 10 & 12 & 14 & 16 & 18 & 20 & 24 & 40 & 70 \\
\hline Liver & \multicolumn{10}{|c|}{ 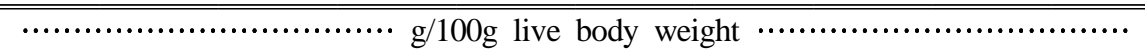 } \\
\hline $\mathrm{C}$ & 2.72 & 2.24 & $2.07^{\mathrm{b}}$ & 2.11 & 1.94 & 2.17 & 2.35 & 2.67 & 2.45 & 2.48 \\
\hline $\mathrm{T} 1$ & 2.56 & 2.53 & $3.18^{\mathrm{a}}$ & 2.23 & 1.85 & 1.94 & 2.16 & 2.40 & 2.50 & 2.47 \\
\hline $\mathrm{T} 2$ & 2.72 & 2.24 & $2.07^{\mathrm{b}}$ & 2.09 & 1.83 & 2.55 & 2.38 & 2.32 & 2.49 & 2.50 \\
\hline SEM & 0.09 & 0.11 & 0.12 & 0.10 & 0.09 & 0.16 & 0.10 & 0.19 & 0.15 & 0.12 \\
\hline Spleen & \multicolumn{10}{|c|}{ 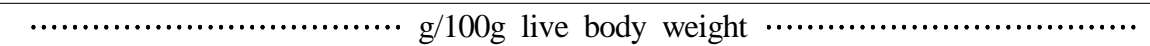 } \\
\hline $\mathrm{C}$ & $0.28^{\mathrm{a}}$ & 0.24 & 0.23 & $0.24^{\mathrm{a}}$ & 0.20 & 0.17 & 0.15 & 0.10 & 0.13 & 0.12 \\
\hline $\mathrm{T} 1$ & $0.22^{\mathrm{b}}$ & 0.25 & 0.22 & $0.17^{\mathrm{b}}$ & 0.20 & 0.22 & 0.12 & 0.10 & 0.14 & 0.13 \\
\hline $\mathrm{T} 2$ & $0.28^{\mathrm{a}}$ & 0.24 & 0.23 & $0.22^{\mathrm{a}}$ & 0.20 & 0.21 & 0.14 & 0.10 & 0.12 & 0.14 \\
\hline SEM & 0.02 & 0.02 & 0.01 & 0.01 & 0.01 & 0.02 & 0.01 & 0.01 & 0.03 & 0.03 \\
\hline
\end{tabular}

$\mathrm{C}$; control, T1 ; restricted feeding started from six to eighteen weeks of age, T2 ; restricted feeding started from twelve to seventeen weeks of age.

a,b Means within columns with no common superscript differ significantly $(\mathrm{P}<0.05)$.

Table 8. Effect of restricted feeding during growing period on body composition

\begin{tabular}{|c|c|c|c|c|c|c|c|c|c|c|}
\hline & \multicolumn{10}{|c|}{ Week of age } \\
\hline & 8 & 10 & 12 & 14 & 16 & 18 & 20 & 24 & 40 & 70 \\
\hline Moisture & \multicolumn{10}{|c|}{ 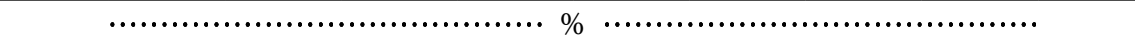 } \\
\hline $\mathrm{C}$ & $69.52^{\mathrm{b}}$ & 69.75 & $68.15^{\mathrm{b}}$ & 67.06 & 67.96 & 65.40 & 66.07 & 65.68 & 66.12 & 65.87 \\
\hline $\mathrm{T} 1$ & $72.28^{\mathrm{a}}$ & 71.99 & $71.35^{\mathrm{a}}$ & 69.05 & 68.52 & 69.49 & 65.98 & 64.14 & 65.75 & 66.13 \\
\hline $\mathrm{T} 2$ & $69.52^{\mathrm{b}}$ & 69.75 & $68.15^{\mathrm{b}}$ & 67.65 & 66.85 & 66.94 & 65.19 & 65.29 & 65.18 & 65.95 \\
\hline SEM & 0.10 & 0.64 & 0.57 & 0.58 & 0.68 & 1.08 & 0.67 & 0.87 & 0.94 & 0.84 \\
\hline Crude protein & \multicolumn{10}{|c|}{ } \\
\hline $\mathrm{C}$ & $17.45^{\mathrm{b}}$ & 18.34 & $18.45^{\mathrm{b}}$ & 18.77 & $18.66^{\mathrm{ab}}$ & 18.18 & 18.71 & 17.37 & 18.01 & 17.95 \\
\hline $\mathrm{T} 1$ & $18.22^{\mathrm{a}}$ & 18.29 & $19.55^{\mathrm{a}}$ & 19.22 & $19.35^{\mathrm{a}}$ & 18.13 & 18.80 & 17.88 & 17.89 & 18.05 \\
\hline $\mathrm{T} 2$ & $17.45^{\mathrm{b}}$ & 18.34 & $18.45^{\mathrm{b}}$ & 19.23 & $18.55^{\mathrm{b}}$ & 18.00 & 18.16 & 17.78 & 17.95 & 17.98 \\
\hline SEM & 0.18 & 0.21 & 0.20 & 0.26 & 0.22 & 0.10 & 0.27 & 0.36 & 0.28 & 0.30 \\
\hline Crude fat & \multicolumn{10}{|c|}{ } \\
\hline $\mathrm{C}$ & 7.32 & $8.20^{\mathrm{a}}$ & $9.56^{\mathrm{a}}$ & 10.80 & $8.66^{\mathrm{ab}}$ & 10.20 & 11.13 & 10.60 & 10.81 & 11.02 \\
\hline $\mathrm{T} 1$ & 4.93 & $4.04^{\mathrm{b}}$ & $4.60^{\mathrm{b}}$ & 8.11 & $7.06^{\mathrm{b}}$ & 7.55 & 10.65 & 12.93 & 11.25 & 10.92 \\
\hline $\mathrm{T} 2$ & 7.32 & $8.20^{\mathrm{a}}$ & $9.56^{\mathrm{a}}$ & 8.30 & $10.42^{\mathrm{a}}$ & 9.57 & 12.35 & 11.33 & 11.27 & 10.88 \\
\hline SEM & 1.02 & 0.74 & 0.53 & 0.83 & 0.68 & 1.05 & 0.69 & 0.94 & 0.84 & 0.55 \\
\hline Crude Ash & \multicolumn{10}{|c|}{ 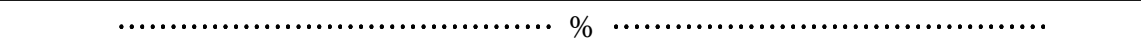 } \\
\hline $\mathrm{C}$ & 3.61 & 3.65 & 3.36 & 3.21 & 3.68 & 3.89 & 3.38 & 3.65 & 3.59 & 3.57 \\
\hline $\mathrm{T} 1$ & 3.73 & 3.48 & 3.67 & 3.53 & 3.74 & 3.29 & 3.62 & 3.31 & 3.42 & 3.34 \\
\hline $\mathrm{T} 2$ & 3.61 & 3.65 & 3.36 & 3.58 & 3.47 & 3.75 & 3.26 & 3.54 & 3.39 & 3.47 \\
\hline SEM & 0.18 & 0.14 & 0.10 & 0.11 & 0.12 & 0.12 & 0.10 & 0.10 & 0.13 & 0.12 \\
\hline
\end{tabular}

$\mathrm{C}$; control, T1 ; restricted feeding started from six to eighteen weeks of age, T2 ; restricted feeding started from twelve to seventeen weeks of age.

a,b Means within columns with no common superscript differ significantly $(\mathrm{P}<0.05)$. 


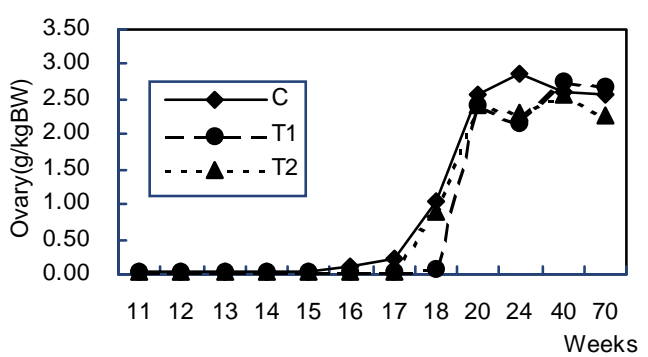

Fig. 1. Effect of restricted feeding during growing period on relative ovary weight.

$\mathrm{C}$; control, $\mathrm{T} 1$; restricted feeding started from six to eighteen weeks of age, T2 ; restricted feeding started from twelve to seventeen weeks of age.

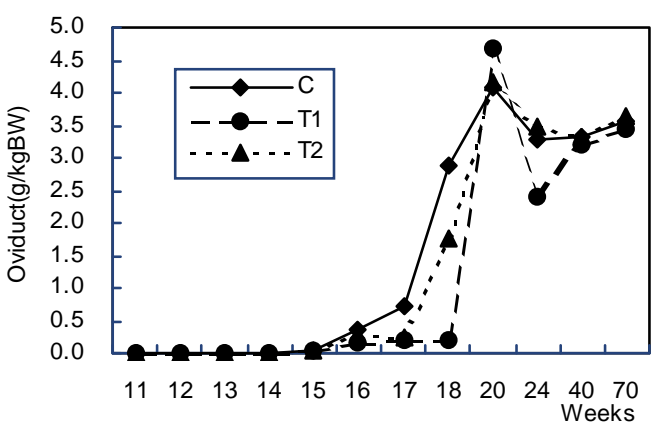

Fig. 2. Effect of restricted feeding during growing period on relative oviduct weight.

$\mathrm{C}$; control, $\mathrm{T} 1$; restricted feeding started from six to eighteen weeks of age, T2; restricted feeding started from twelve to seventeen weeks of age.

(Fig. 3).

Estradiolo 은 6주령 이후 전체적으로 증가하는 양상을 보였는데 그 패턴에서 처리 간 차이를 보였다. 대조구의 경우 산란개시기에 급격한 증가를 보였는데 이후 증가, 감소를 큰 농도 차이에서 반복하는 양상을 보였다. $\mathrm{T} 1$ 처리구 와 $\mathrm{T} 2$ 처리구의 경우 증가양상은 비슷하지만 지속적으로 큰 차이 없이 증가해 간다는 점에 서 대조구와 차이점을 보였다. 일반적으로 산 란이 저하되는 시점에서 estradiol의 농도가 감 소될 것으로 예측되었으나 전 기간동안 꾸준한 증가가 이루어졌으며 종료시점에서도 estradiol 의 함량은 높게 나타났다.

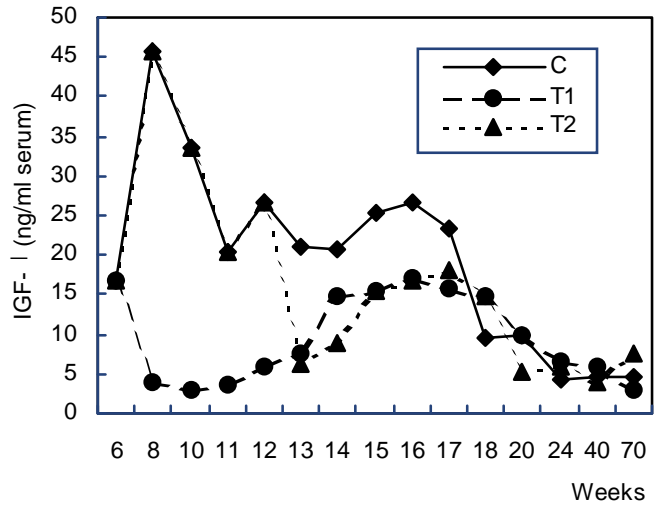

Fig. 3. Effect of restricted feeding during growing period on IGF- I concentration. C; control, T1; restricted feeding started from six to eighteen weeks of age, T2 ; restricted feeding started from twelve to seventeen weeks of age.

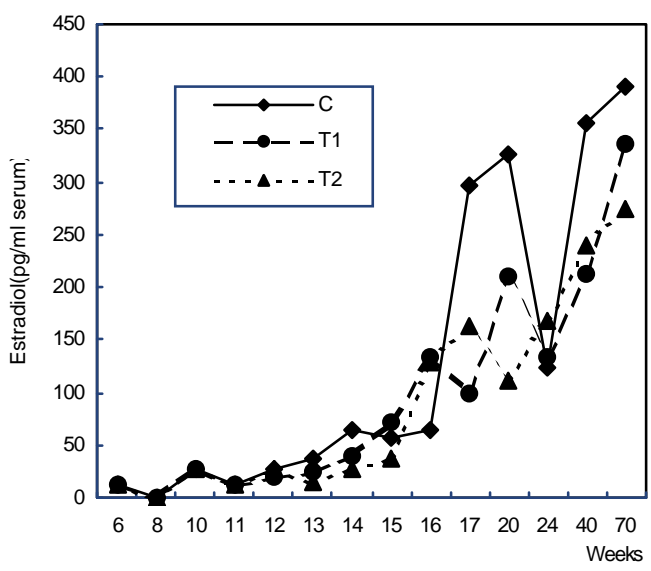

Fig. 4. Effect of restricted feeding during growing period on estradiol concentration. $\mathrm{C}$; control, T1; restricted feeding started from six to eighteen weeks of age, T2 ; restricted feeding started from twelve to seventeen weeks of age.

산란계에서 estradiol의 주입은 간에 의해 지 방단백질을 선행하는 난황의 생산을 야기 시키 고 난관의 발달을 자극시키며 칼슘대사를 조정 하는 것으로 알려져 있다 (Walzem, 1996; Chen 등, 1999; Walzem 등, 1999; Johnson, 2000). 육 용종계를 대상으로 자유채식과 제한급여를 시 킨 결과 estradiol의 유의성은 검증되지 않았으 며(Liu 등, 2004; Onagbesan 등, 2006; Buchianan, 2000) estradiol의 함량은 모든 처리에서 성성숙 
이후에 증가하였으나 제한급여 처리에서 지연 되었다고 보고되었다(Onagbesan 등, 2006).

본 연구에서 estradiol의 수준은 산란개시시점 이후 급격한 증가양상을 나타내었는데, 증가양 상은 제한급여 처리에서 안정적으로 나타났는 데 이는 산란계 육성기에 제한급여 시 체내 균 형이 안정화되어 발생되어진 결과로 사료된다.

\section{IV. 요 약}

본 연구는 산란계의 육성기 제한급여가 체성 장 특성 및 내분비 변화에 미치는 영향을 구명 하고자 1 일령 갈색산란계 Isa-brown 1,080수를 공시하여 시험을 실시하였다. 육성기 제한급여 처리내용으로는 자유채식, 6 18주령까지 제한 급여, 12 18주령까지 제한급여를 각각 실시하 였으며 모든 사료영양소 함량 및 단계별 사료 급여는 $\mathrm{NRC(1994)에} \mathrm{준하여} \mathrm{실시하였다.} \mathrm{육성}$ 기간동안 체중과 사료섭취량은 6 18주령 제한 급여 처리구가 가장 낮았으나 $(\mathrm{P}<0.05) 20$ 주령에 서 각 처리구간 유의적 차이는 나타나지 않았 다. 소화기관 및 실질장기 발달은 처리구간에 뚜렷한 차이는 없었으나 육성기간동안 체중이 낮았던 제한급여 처리구에서 다소 높은 비율을 보였다.

체조성은 지방 함량에서 처리구간 유의성이 나타났는데 자유급여 처리구에 비해 6 18주령 제한급여 처리구에서 육성기간동안 유의적으로 낮게 나타났다 $(\mathrm{P}<0.05)$. IGF- I 는 육성기간동안 높은 수준을 보였으나 번식기관이 발달하는 시 기부터 급격히 하락하여 낮은 수준으로 유지되 면서, 사료섭취량에 민감한 반응을 보였다. estradiol은 6주령 이후 전체적으로 증가하는 양 상을 보였는데 16 17주령 사이에 증가하는 양상 을 보였으며 종료 시까지 높은 수준을 유지하였 는데 처리구간에 유의성은 나타나지 않았다.

이상의 결과에서 6 18주 제한급여 처리구가 육성기간동안 체중, 증체량 및 사료섭취량은 자유급여 처리구에 비해 낮았으며 $(\mathrm{P}<0.05)$, 지 방함량 또한 적게 나타났다 $(\mathrm{P}<0.05)$. 따라서 육 성기 제한급여를 육성초기에 실시할 경우 체내 대사에 있어 큰 영향을 미치지 않았으며 estradiol 수준 역시 안정적으로 나타났다. 따라 서, 본 연구 결과는 육성기 제한급여가 산란계 성장에 있어서 내분비와 체성장 조성에 영향하 지 않으며 또한, 최근 곡물가격의 상승으로 인 한 사료가격의 상승에 대한 문제를 해결 할 수 있는 해결방안으로 충분한 가치가 있을 것으로 사료된다. 하지만, 좀 더 개선되어져야 할 부분 이 많은 만큼 향후 지속적으로 제한 급여 수준 및 기간 등에 관한 세밀한 연구가 이루어져야 할 것으로 사료된다.

(색인어: 산란계, 제한급여, Insulin-like growth factor- I, 체성분)

\section{$\mathrm{V}$. 인 용 문 헌}

1. AOAC. 1995. Official methods of analysis, 15th edition. Association of Official Analytical. Chemists. Washington. DC.

2. Buchianan, S., Robertson, G. W. and Hocking, P. M. 2000. Effects of food restriction or delayed photostimulation on ovarian follicle number, plama oestradiol concentration and vaginal collagen content in male-line turkeys. Br. Poult. Sci. 41: 502-507.

3. Chen, S. E., Long, D. W., Nestor, K. E., Walzem, R. L., Meuniot, V. L., Zhu, H., Hansen, R. J. and Bacon, W. L. 1999. Effect of divergent selection for total plasma phosphorus on plasma and yolk very-low density lipoproteins and plasma concentration of selected hormones in laying Japanese quail. Poult. Sci. 78:1241-1251.

4. Darras, V. M., Buyse, J., Decuypere, E. and Kuhn, E. R. 1995. Hormonal and nutritional influence on thyroid hormone deiodinating enzymes. Poultry and Avian Biology Reviews. 6:314.

5. Daughaday, W. H. 1978. Cushing's disease and basophilic microadenomas. J. New England. 298: 793-794.

6. Dunnington, E. A. and Siegel, P. B. 1984. Age and body weight at sexual maturity in female white Leghorn chickens. Poult. Sci, 63:828-830.

7. Dunnington, E. A., Siegel, P. B., Cherry, J. A. and Soller, M. 1983. Archiv Geflugelkunde. 47:87-89.

8. Fattori, T. R., Wilson, H. R., Harms, R. H., Mather, F. B., Miles, R. D. and Butcher G. D. 1993. Response of broiler breeder females to feed 
restriction below recommended levels. 3. Characterizing the onset of sexual maturity. Poult. Sci. 72:2044-2051.

9. Frankham, R. and Doornenbal, H. 1970. Physiological differences associated with genetic differences in egg production. 3. Gonadotrophin sensitivity. Poult. Sci. 49:1619-1621.

10. Fryburg, D. A. 1994. Insulin-like growth factor I exerts growth hormone-and insulin-like actions on human muscle protein metabolism. Endocrinol. Metab. 30:331-336.

11. Gonzales, E., Buyse, J., Loddi, M. M. Takita, T. S., Buys, N. and Decuypere, E. 1998. Performance, incidence of metabolic disturbances and endocrine? variables of food-restricted male broiler chickens. Br. Poult. Sci. 39:671-678.

12. Hollands, K. G. and Gowe, R. S. 1961. The effect of restricted and full-feeding during confinement rearing on first and second year laying house performance. Poult. Sci. 40:574-583.

13. Johnson, A. L. 2000. Reproduction in the female. Sturkie’s Avian Physiology. pp 569-596.

14. Katanbaf, M. N., Dunnington, E. A. and Siegel, P. B. 1988. Allomorphic relationships from hatching to 56 days in parental lines and F1 crosses of chickens selected 27 generations for high or low body weight Growth Dev. Aging 52:11-22.

15. Katanbaf, M. N., Dunnington, E. A. and Siegel, P. B. 1989. Restricted feeding in early and late-feathering chickens. 2. Reproductive responses. Poult. Sci. 68:352-358.

16. Kwakkel, R. P., Ducro, B. J. and Koops, W. J. 1993. Multiphasic analysis of growth of the body and its chemical components in White Leghorn pullets. Poult. Sci. 72:1421-1432.

17. Lee, C. Y. and Henricks, D. M. 1990. Comparisions of various acidic treatments of bovine serum on insulin-like growth factor- I immunoreactive and binding activity. Endocrinol. 127: 139-148.

18. Liu, H. -K., Lilburn, M. S., Koyyeri, B., Anderson, J. W. and Bacon, W. L. 2004. Preovulatory surge patterns of luteinizing hormone, progesterone, and estadiol-17 $\beta$ in broiler breeder hens fed ad libitum or restricted fed. Poult. Sci. 83:823-829.

19. Melnychuk, V. L., Kirby, J. D., Kirby, Y. K.,
Emmerson, D. A. and Anthony, N. B. 2004. Effect of strain, feed allocation program, and age at photostimulation on reproductive development and carcass characteristics of broiler breeder hens. Poult. Sci. 83:1861-1867.

20. National Research Council. 1994. Nutrient requirements of poultry. National Academy Press, Washington, D.C.

21. Onagbesan, O. M., Metayer, S., Tona, K., Williams, J., Decuypere, E. and Bruggeman, V. 2006. Effects of genotype and feed allowance on plasma luteinizing hormones, follicle-stimulating hormones, progesterone, estradiol levels, follicle differentiation, and egg production rates of broiler breeder hens. Poult. Sci. 85:1245-1258.

22. Palo, P. E., Sell, J. L., Piquer, F. J., SotoSalanova, M. F. and Vilaseaca, L. 1995. Effect of early nutrient restriction on broiler chickens. 1 . Performance and development of the gastrointestinal tract. Poult. Sci. 74:88-101.

23. SAS institute 1996. SAS/STAT Guide Version 6.12 SAS, Institute Inc., Cary, NC.

24. Walzem, R. L. 1996. Lipoproteins and laying hens: Form follows function. Poultry. Avian Biol. Rev. 7:31-64.

25. Walzem, R. L., Hansen, R. H., Williams, D. L. and Hamilton, R. L. 1999. Estrogen induction of VLDLy assembly in egg-laying hens. J. Nutr. 129:467-472.

26. Watson, N. A. 1975. Reproductive activity of broiler hens subjected to restricted feeding during rearing. Br. Poult. Sci. 16:259-262.

27. Wells, R. G. 1980. In Recent Advances in Animal Nutrition. pp. 185-202.

28. Wilson, H. R, Ingram, D. R. and Harms, R. H. 1983. Restricted feeding of broiler breeders. Poult. Sci. 62:1133-1141.

29. 김상호, 장병귀, 최철환, 서옥석, 이상진, 류경선. 2003. 산란계 육성기 제한급이가 초기 산란 특징 에 미치는 영향. 한국가금학회 2003 학술발표회 Proceedings. p 97-98.

30. 이규호, 김덕교. 1974. 육성기 사료의 양적 제한 급여가 육용종계의 발육 및 난생성에 미치는 영 향. 한국동물자원과학회. 16:349-356.

31. 한국표준가축사료급여기준(닭). 1994. 축산시험장. (접수일자 : 2008. 3. 3. / 수정일자 : 2008. 5. 16. /

채택일자 : 2008. 6. 5) 